\title{
システムの作動状態をドライバに理解させるための視覚情報提示手法
}

\author{
O宮内 萌衣（日本大学大学院），石橋 基範（日本大学）
}

\section{A Method of Visual Information Presentation for Understanding System Status by Driver}

\section{Moe MIYAUCHI (Graduate School of Nihon University)， Motonori ISHIBASHI (Nihon University)}

\section{1.はじめに}

運転の負担軽減に向けて、先進運転支援システ ム (ADAS) の開発が進められている。ADASの 効果が見込まれる一方で、一般のドライバには作 動状態や制御ロジックが分かりにくい機能もある。 そのため、「状況認識」の理解、予測が正しく行 われない場合に、ドライバがシステムに期待する 支援とドライバが行うべき操作への認識が異なり、 ヒューマンエラーに繋がる可能性がある。

それに対して、自動車基準調和世界フォーラム （WP29）から高度運転支援システムのHMI原則 ガイドラインが示されている1)。しかし、システ ムの意図をドライバに的確に提示する方法につい ては今後の検討が必要な課題とされている。特に、 作動頻度が低いシステムではドライバに確実に意 図を伝えることが必須である。

そこで本研究では、システムの作動状態をドラ イバに的確に理解させる視覚情報提示の手法につ いて検討する。事例として、ドライバ異常時対応 システム（ドライバの異常を検知したら自動停止 や緊急通報するシステム）2を取り上げる。

\section{2. 方法}

\section{1 実験参加者}

普通自動車免許を持つ20歳 代の男女大学生及び大学院生 28名とした。

2.2 実験方法

(1) 実験装置

実験装置を図1に示す。着座 姿勢とし、車載表示器を模し たPCディスプレイとの視距離 は約 $0.8 \mathrm{~m}$ とした。

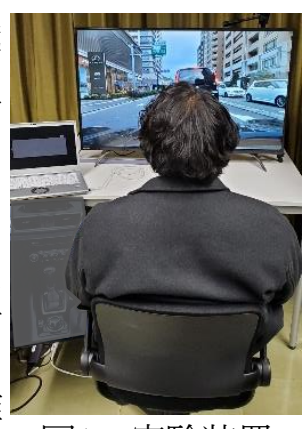

図1 実験装置
(2) 評価サンプルの作成方法

評価サンプルはペイントソフト（MediBang Paint）で作成した。評価サンプルを作る際の条 件設定に、情報提示によって求める「判断」「操 作」の2つのタスク（後述）に対して土台となる Baseを設けた（図2）。そして、Baseについて行っ たインタビュー調査から改善課題を検討し、その 改善策を実験条件として織り込んで策定した。
実験条件はタスクごとに3つの改善条件を追加 した。判断タスク（図2／上側）は、A：システ ムが異常と判断するに至った検知内容、 B : 検知 内容十重大性の 情報表示、C :

「検知内容 + 重 大性の情報表 示」十強調表示 とした。操作夕 ドライバの異常を検知したため。 緊急停車します

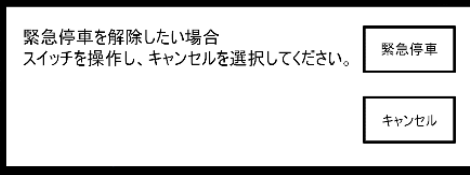
スク（図2/下 図2 評価サンプルの例 側）は、操作対象の条件操作対象 操作方法 表現、操作方法の表 現の仕方を表1のよ うに設定した。 (3) 実験タスク

\begin{tabular}{|c|l|l|}
\hline$P$ & テキスト & テキスト \\
\hline$Q$ & 静止画像 & テキスト \\
\hline$R$ & 静止画像 & 動画(GIF) \\
\hline
\end{tabular}

本研究では、「運転中に渋滞が発生したため、 リクライニングをしてリラックスしている場面で ドライバ異常時対応システムが作動した」状況を 想定した。すなわち、この状況ではドライバは正 常であるため、システムを実行させないことがド ライバに求められる判断である。実験タスクは、 心理学実験ソフトウェアである SuperLab5.0 （Cedrus社）を用いて作成した。そして、報知音 （正弦波）と共にPCディスプレイに前述の評価 サンプルを提示し、その後、以下に示す「反応の 基準」に達したら実験参加者は手元の反応作業用 レスポンスパッドのボタンを押して反応した。

判断タスク : 参加者は、提示されたシステムを 実行するか否か判断ができたら、その判断をボタ ン押しで回答した。その後、判断を下した理由、 および判断が状況に即した適切なものであるとい う確信度（0～100\%）を口頭で回答をした。

操作タスク : 参加者は、判断タスクでの判断を 実現するための操作内容を理解できたら、ボタン 押しで反応した。そして、操作内容と、自身の理 解が正しいという確信度を口頭で回答した。

サンプル提示からボタン押下までの時間を「理 解に要する時間」として計測した。また、各評価 サンプルについてSUS（System Usability Scale） 3) による使いや寸さの主観評価を行った。 


\section{(4) 手続き}

判断タスクを行い、続けて操作タスクを終える までを1試行とした。実験参加者はBase-Baseの条 件を1試行と、各タスクの改善条件から1試行（総 当たりで9パターンのうち1つ）を行った。

\section{3 解析方法}

ユーザビリティの「有効さ」「効率性」「満足度」 の観点から指標を設定した。次に、「理解に要す る時間」から極端に遅いデータは取り除いた。ま た、本研究に用いた操作部の名称や操作方法を実 験参加者が既知の場合は、操作タスクのデータか ら取り除いた。なお、統計解析で有意水準は $5 \%$ に設定した。

\section{3 . 結果}

\section{1 正答率・確信度（有効さ）}

各条件での正答率と正答者の回答確信度の平均 を表2に示す。 表2 正答率と確信度

\begin{tabular}{|c|c|c|c|c|c|}
\hline \multirow{2}{*}{$\begin{array}{l}\text { 正答率は、すべ } \\
\text { ての改善条件が }\end{array}$} & 条件 & $\mathrm{N}$ & 正答率 $(\%)$ & 正答者数 & 確信度 $(\%)$ \\
\hline & Base & 27 & 74.1 & 20 & 84.8 \\
\hline \multirow{3}{*}{$\begin{array}{l}\text { Base の值を上 } \\
\text { 回った。 } \\
3.2 \text { 理解に要す }\end{array}$} & A & 10 & 90.0 & 9 & 78.3 \\
\hline & $B$ & 9 & 100.0 & 9 & 80. \\
\hline & $c$ & 9 & 100.0 & 9 & 76.7 \\
\hline \multirow{3}{*}{ る時間（効率 } & Base & 25 & 4. 0 & 1 & 60.0 \\
\hline & $P$ & 9 & 77.8 & 7 & \\
\hline & $Q$ & 7 & 71.4 & 5 & 88.0 \\
\hline 正しい理解に & $R$ & 9 & $\begin{array}{ll}77.8 \\
\end{array}$ & 7 & 89.2 \\
\hline
\end{tabular}
めるため、正答した実験参加者の結果に着目した。 (1) 判断タスクにおける理解に要する時間

適切かつ速い判断が求められるため、Baseに対 する理解に要する時間が長い (4.0s以上) 参加者 のデータに注目した。条件ごとに算出した、理解 に要する時間の平均を図3に示す。N数はそれぞ れ10、5、5、6であった。改善の度合いに応じて 標準偏差 (個人差) に減少傾向が見られた。

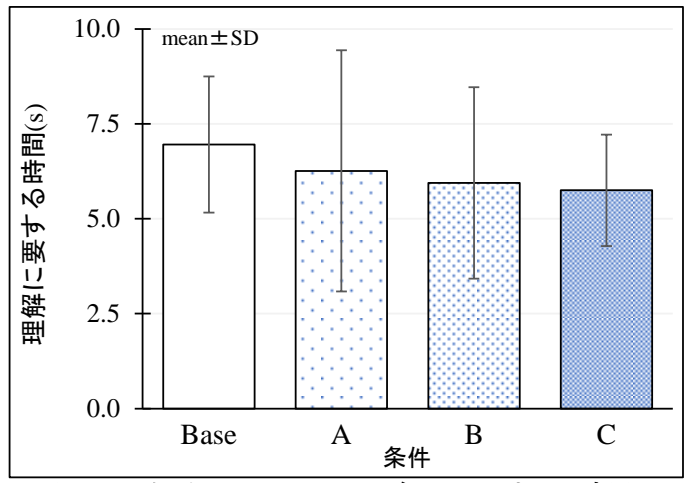

図3 判断タスクの理解に要する時間

(2) 操作タスクにおける理解に要する時間
条件ごとに算出した、操作タスクの理解に要す る時間の平均を図4に示す。 $\mathrm{N}$ 数はそれぞれ1、7、 5、6であった。マン・ホイットニーのU検定にお いて、条件 $\mathrm{R}$ 条件 $\mathrm{P}$ の間 $(\mathrm{p}<0.05)$ 、および条件 $\mathrm{R}$ と条件 $\mathrm{Q}$ の間 $(\mathrm{p}<0.01)$ で有意差が認められた。

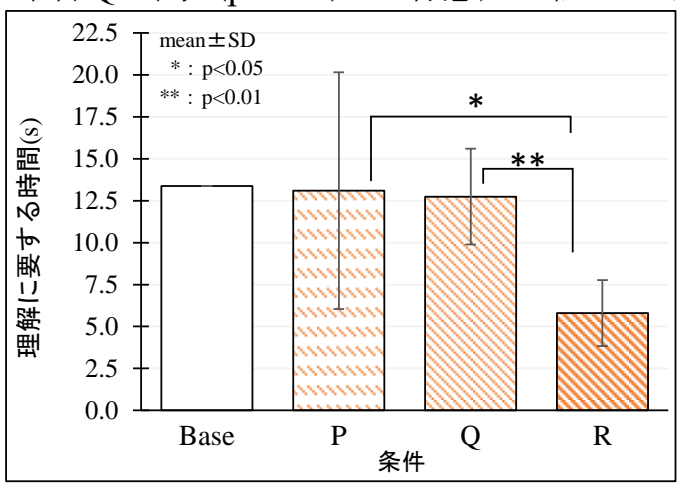

図4 操作タスクの理解に要する時間

3.3 主観評価（満足度）

SUSは平均得点が68.1点とされる。Baseとの比 較で得点が最も向上し、平均值を上回ったのは条 件Rだった（73.3点）。サンプル内の文字数 $(x)$ に着目し回帰分析を行った結果、以下の主観評価 得点 $(y)$ 予測式が得られた $\left(R^{2}=0.54, \mathrm{p}<0.05\right)$ 。 $y=-0.73 x+83.86$

\section{4. 考察・まとめ}

「システムを実行するか否か」の判断を求める には、表示に重大性の情報の付加や、強調表示す ることで理解に要する時間の個人差の低減が可能 になると考えられる。また、「判断を実現するた めの」操作内容の理解を求めるには、操作方法を 動画によって表現することで理解に要する時間の 短縮が可能になると考えられる。

さらに、車内情報のシンボル表示が分かりにく いという意見が時折見られるが、それも踏まえる と、状況や出来事等のドライバにとって曖昧な事 象は文章で具体的に、装置（具体的なモノ）は静 止画や動画で伝えるのが適切である可能性がある。

本研究は日本大学生産工学部「人を対象とする研 究倫理審査委員会」の承認を得て実施した。

\section{参考文献}

1) 向江ら：高度運転支援システムのHMI原則，計 測と制御，Vol.54，No.11，pp.841-844， 2015.

2) 国土交通省 : ドライバー異常時対応システムの概 要, https://www.mlit.go.jp/common/001124852.pdf (参照2021-1-10)

3) John Brooke : SUS - A quick and dirty usability scale, https://hell.meiert.org/core/pdf/sus.pdf（参照2021-1-10） 